\title{
Quality assessment of ice-stored tropical yellowfin tuna (Thunnus albacares) and influence of vacuum and modified atmosphere packaging
}

\author{
Silbande Adèle ${ }^{1,2,3}$, Adenet Sandra ${ }^{1}$, Smith-Ravin Juliette ${ }^{2}$, Joffraud Jean-Jacques ${ }^{3}$, \\ Rochefort Katia ${ }^{1}$, Leroi Françoise ${ }^{3, *}$
}

\begin{abstract}
${ }^{1}$ Pôle Agroalimentaire Régional de Martinique (PARM), Impasse Petit-Morne, № 375, 97232 Lamentin, Martinique

${ }^{2}$ Université des Antilles, Département Scientifique Inter facultaire (DSI), EA929 AIHP-GEODE (groupe BIOSPHERES), BP 7209, 97275 Schœlcher, Martinique

${ }^{3}$ Ifremer, Laboratoire Ecosystèmes Microbiens et Molécules Marines pour les Biotechnologies (EM3B), rue de l'lle d'Yeu, BP 21105, 44300 Nantes, France

* Corresponding author : Françoise Leroi, email address : Francoise.Leroi@ifremer.fr

adele.silbande@gmail.com ; adenet@parm.asso.fr ; jsmithra@martinique.univ-ag.fr ; Jean.Jacques.Joffraud@ifremer.fr ; rochefort@parm.asso.fr
\end{abstract}

\begin{abstract}
:
Metagenomic, microbial, chemical and sensory analyses of Thunnus albacares from Martinique and stored in ice (AIR $-0{ }^{\circ} \mathrm{C}$ ), vacuum (VP $-4 / 8{ }^{\circ} \mathrm{C}$ ) and modified atmosphere packaging (MAP $-4 / 8^{\circ} \mathrm{C}$ ) $\left(70 \% \mathrm{CO}_{2}-30 \% \mathrm{O}_{2}\right)$ were carried out. The organoleptic rejection of AIR tuna was observed at day 13 when total bacterial counts equaled $10^{6}-10^{7} \mathrm{CFU} \mathrm{g}^{-1}$. No extension of shelf-life was provided by VP and MAP. According to $16 \mathrm{~S}$ rRNA gene sequence analyzed by lllumina MiSeq and PCR-TTGE, Rhodanobacter terrae was the main species of the freshly caught tuna. At the sensory rejection time, Brochothrix thermosphacta and Pseudomonas dominated the AIR products while $B$. thermosphacta alone or a mix of $B$. thermosphacta, Enterobacteriaceae and lactic acid bacteria (LAB) dominated the microbiota of MAP and VP products, respectively. The $\mathrm{pH}$ value remained stable in all trials, ranging from 5.77 to 5.97. Total volatile basic nitrogen (TVBN) and trimethylamine (TMA-N) concentrations were weak and not significantly different between batches. Lipid oxidation increased in the samples containing $\mathrm{O}_{2}$ (MAP > AIR). The initial concentration of histamine was high $\left(75-78 \mathrm{mg} \mathrm{kg}^{-1}\right.$ ) and stable up to 8 days but then significantly decreased in all trials to reach $25-30 \mathrm{mg} \mathrm{kg}^{-1}$, probably due to the presence of histamine-decomposing bacteria.
\end{abstract}

Keywords : Seafood, Fish, Microbiology, Sensory, NGS, 16S rRNA gene 


\section{Introduction}

The spoilage of food refers to a loss of initial quality rendering it less palatable or toxic for human consumption (Ashie et al., 1996; Gram et al., 2002). Fish flesh is an extremely perishable product due to both microbial spoilage and biochemical reactions occurring during processing and storage. The high water activity, high postmortem $\mathrm{pH}(>6)$ and large amounts of low molecular weight components make it an ideal substrate for bacterial growth, which is essentially responsible for the sensory deterioration (Dainty, 1996; Gram and Huss, 1996; 2000; Shewan, 1971).

The use of ice is probably the simplest method for delaying fish spoilage and the benefits in the tropics are greater than in cold or temperate areas (Liston, 1980;

Poulter et al., 1981; Sumner et al., 1984). Moreover, VP and MAP in combination with refrigeration are widely used to extend the shelf-life of fish products (Cakli et al., 2006; Dalgaard et al., 1993; Goulas and Kontominas, 2007; Reddy et al., 1992;

Sivertsvik et al., 2002).

Fishery products are also responsible for outbreaks resulting from contamination by bacterial pathogens, biotoxins, histamine, viruses or parasites (Galaviz-Silva et al., 2009). Histamine fish poisoning (HFP) is the first cause of fish-related foodborne infection in France, which is due to the ingestion of a high concentration of histamine produced by the bacterial decarboxylation of free histidine (Frank et al., 1985; Hungerford, 2010; Lehane and Olley, 2000). Scombroid fish, such as tuna, generally possess a high content of free histidine in their muscle tissues and are most commonly associated with HFP (Lukton and Olcott, 1958; Taylor and Eitenmiller, 1986).

Worldwide, the yellowfin tuna (Thunnus albacares) predominates in tropical and subtropical waters and 1.3 MT were caught in 2012 (FAO, 2014). In Martinique, T. 
albacares represents one of the main pelagics caught by long-line fleets around fish aggregating devices. Approximately $85 \mathrm{~T}$, with a value of more than $800000 \mathrm{US}$ dollars, were captured in 2010 (Reynal et al., 2011). In this region, the marine catch is carried out manually in traditional non-mechanized vessels operated by one or two fishermen. Post-harvest treatments are not standardized but fish are generally gutted on board, iced in a cooler box and sold along the road, sometimes more than 48 hours after fishing. Two HFP outbreaks (137 people) due to the consumption of yellowfin tuna were observed in 2007-2008 in Martinique (Duflos, 2009). Although some studies are available on the quality of raw yellowfin tuna, most of them concern tuna from the Indian or Pacific Ocean (Cramer et al., 1981; Du et al., 2001; Du et al., 2002; Emborg et al., 2005; Ferrario et al., 2012; Gill et al., 1987; Guizani et al., 2005; Kanki et al., 2007; Lee et al., 2003; Saito et al., 1996; Sika et al., 2014;

Staruszkiewicz et al., 2004; Susanto et al., 2011; Widiastuti et al., 2013). In addition to a lack of information in tropical areas, none of these works used culture-independent microbial techniques, such as temporal temperature gradient gel electrophoresis (TTGE) or next-generation sequencing (NGS), to characterize the microbiota in detail. Recently, these methods have been successfully employed for the evaluation of microbial ecosystems of various seafoods such as cod, raw and smoked salmon and shrimp (Chaillou et al., 2014; Giacomazzi et al., 2004; Jaffrès et al., 2009; Leroi et al., 2015; Macé et al., 2012; Rachman et al., 2004).

The aims of this work were to monitor the quantitative and qualitative evolution of the microbiota of raw yellowfin tuna flesh and to investigate the effect of packaging storage on quality. Microbiological (culture-dependent and culture-independent methods), chemical and sensory analyses were carried out on tuna stored under air, VP and MAP. 


\section{Materials and Methods}

90

\subsection{Tuna sampling}

A yellowfin tuna caught off the Caribbean coast of Martinique was purchased from a fish landing point at Bellefontaine (1440'22'”; 6 109'51'”W) in May 2014. The fish was bled and gutted on board and stored in ice in a large cooler box. The fish weight without head and tail was $37.8 \mathrm{~kg}$. The tuna was cut by the seller into slices $(4-5 \mathrm{~cm}$ thick) which were put into plastic bags and transported in a clean plastic ice box to the PARM laboratory within 45 min of slicing.

\subsection{Storage conditions}

Upon arrival, slices were placed in a room at $12^{\circ} \mathrm{C}$. Each slice was portioned into 4

quarters with skin (steaks) weighing 400 to $600 \mathrm{~g}$. Steaks were divided into 3 batches. For the first batch (VP), steaks were vacuum-packed individually in $80-\mu \mathrm{m}$ thick plastic bags (Garcia de Pou, Girona, Spain) made of polyamide/polypropylene with a gas-permeability of $2.78 \mathrm{~cm}^{3} / \mathrm{m}^{2} /$ day for water vapor, $19.95 \mathrm{~cm}^{3} / \mathrm{m}^{2} /$ day for $\mathrm{O}_{2}$ and $164.87 \mathrm{~cm}^{3} / \mathrm{m}^{2} /$ day for $\mathrm{CO}_{2}$ using a packaging machine (Multivac, Lagny sur Marne, France). For the second batch (AIR), steaks were placed in the same type of plastic bags. These samples were iced in a cooler box by alternating a layer of fish with a layer of ice and kept in a cold room $\left(4^{\circ} \mathrm{C}\right)$. To maintain AIR samples at $0^{\circ} \mathrm{C}$, melting water was drained off and ice was replaced when necessary. Steaks of the third batch (MAP) were placed on a filmed plastic tray and packed under a modified atmosphere $\left(70 \% \mathrm{CO}_{2}, 30 \% \mathrm{O}_{2}\right)$ using a Meca 500 machine (Mecapack, Pouzauges,

112 France). The properties of the polyamide/polypropylene film used (Pechiney, Paris, 
113 France) were a thickness of $90 \mu \mathrm{m}$ and a gas-permeability $\left(\mathrm{cm}^{3} / \mathrm{m}^{2} /\right.$ day at $23{ }^{\circ} \mathrm{C}, 50 \%$

$114 \mathrm{RH}$ ) of $4,30,120$ and 6 for water vapor, $\mathrm{O}_{2}, \mathrm{CO}_{2}$ and $\mathrm{N}_{2}$, respectively. VP and MAP

115 samples were stored at $4^{\circ} \mathrm{C}$ for the first week and then at $8^{\circ} \mathrm{C}$, according to the

116 French standard shelf-life validation of perishable and refrigerated food (AFNOR,

117 2010). For each batch, 3 steaks were analyzed at five predetermined time intervals

118 and tested for sensory, bacteriological and chemical qualities until they were

119 organoleptically unacceptable. The sampling times were $0,6,8,10$ and 13 days for

120 AIR and 0,8 and 13 days for VP and MAP. The mean value of the triplicate was used

121 as a representative value of the sample.

122

123

\subsection{Chemical analysis}

124

2.3.1. Total volatile basic nitrogen (TVBN) and trimethylamine (TMA-N)

125

TVBN and TMA-N were determined for $100 \mathrm{~g}$ of fish using the Conway

126

micro-diffusion method (Conway and Byrne, 1933).

127 2.3.2. $\mathrm{pH}$

128 Twenty grams of fish muscle was stomached with $80 \mathrm{ml}$ of distilled water in a stomacher 400 (Seward Ltd., London, UK) and the $\mathrm{pH}$ was measured immediately on the homogenate using a pH-meter (Inolab, Germany).

\subsubsection{Thiobarbituric acid (TBA) index}

132 The extraction procedure and TBA reaction described by Vyncke, 1970 were used.

133 After cooling in tap water, $4 \mathrm{ml}$ of methanol was added and absorbance of the

134 methanol-water phase was read at $532 \mathrm{~nm}$ with a spectrophotometer (Jenway,

135 Stafford, UK). The amount of malonaldehyde (MDA) was calculated by dividing the

136 absorbance by the slope of the standard curve prepared using 
137 1,1,3,3-tetraethoxypropane and multiplying by a factor of 86.4. TBA (mg-MDA kg-1)

138 was analyzed at the first and last sampling point for the 3 batches.

\section{2.3.4. Histamine}

140 Histamine content was determined in $50 \mathrm{~g}$ of fish muscle by a colorimetric assay

141 method with a commercial rapid histamine test kit (RIDA ${ }^{\circledR}$ QUICK Histamin from

142 R-Biopharm AG, Darmstadt, Germany) according to the manufacturer's

143 recommendations.

\subsection{Sensory analysis}

Based on preliminary visual and olfactory acuity tests, 6 people from the permanent

staff of PARM were selected to evaluate the sensory quality of $T$. albacares. Two training sessions were carried out. First, panelists were trained with concentrated aromatic molecules in an ethanol solution (Table 1). These molecules had been identified as related to odors of spoiled fish (Joffraud et al., 2001; Selli et al., 2006). Panelists met for another session using fresh and spoiled samples of yellowfin tuna in order to establish a list of descriptors and a fairly uniform degree of sensory evaluation. The following attributes were retained: marine, amine, sulfur and pungent for odor and blood red, slightly pink, bleached, grayish, browned and greenish for color. At each sampling date, 4 to 5 panelists had to score the odor, color and texture of the tuna samples on a 10-point scale, with 0 representing fresh fish and 10 rotten fish. Panelists received a fresh flesh sample (tuna flesh that had been frozen at $-80^{\circ} \mathrm{C}$ and thawed for each sensory analysis sessi on) as a reference. The sample consisted of 20 grams of each tuna steak of the triplicate pooled in a single opaque bowl coded with random 3-digit numbers. An average of the levels of odor, color and texture was calculated for each sample to give an overall spoilage score. When a 
162

163

164

165

166

167

168

169

170

171

172

173

174

175

176

177

178

179

180

181

182

183

184

185

batch reached a spoilage score equal to or more than 6 points, it was considered rejected and the experiment was stopped. For odor and color aspects, panelists selected zero, one or more attributes defined by an intensity class (slight, moderate and strong). Each characteristic was associated with an index (I) defined as follows:

$\mathrm{I}=\frac{1 \times \text { PP }_{\text {SLIGHT }}+2 \times \text { PPMODERATE }+3 \times \text { PP }_{\text {STRONG }}}{100}$

where PP is the percentage of panelists who selected the corresponding intensity class.

This index varies from 0 (the characteristic was not selected) to 3 (all panelists chose strong for the characteristic).

\subsection{Enumeration of bacterial groups}

From each sample, a 30-g portion of fish flesh was added to $120 \mathrm{ml}$ of sterile Tryptone-salt broth (Biokar Diagnostic, Beauvais, France) containing $0.2 \%$ of Tween 80 (Sigma-Aldrich ${ }^{\circledR}$, St Louis, MO, USA) and stomached for 2 min with a stomacher 400 (Seward) to obtain the mother solution. Total Mesophilic Viable Counts (TMVC) were enumerated on a pour plate of Plate Count Agar (PCA) (AES Laboratory, Bruz, France) with $0.5 \% \mathrm{NaCl}$ after 3 days at $30^{\circ} \mathrm{C}$. Total Psychrotrophic Viable Counts (TPVC), lactic acid bacteria (LAB) and B. thermosphacta were enumerated on spread plates of Long and Hammer agar with $1 \% \mathrm{NaCl}(\mathrm{LH})$ (Van Spreekens, 1974), Elliker agar (ELK) and Streptomycin Sulfate Thallous Acetate Agar (STAA), respectively, according to Leroi et al., 2015. Pseudomonas spp. were counted on spread plates of CHROMagar ${ }^{\mathrm{TM}}$ (CHROMagar, Paris, France) after $24-48 \mathrm{~h}$ at $20^{\circ} \mathrm{C}$.

Enterobacteriaceae were enumerated on pour plates of Caso agar (Merck, Darmstadt, Germany) overlaid by Violet Red Bile Glucose Agar (VRBGA, BioRad, Marnes-la-Coquette, France) called Caso/VRBG and incubated for 2 days at $20^{\circ} \mathrm{C}$. 


\subsection{Isolation, purification and identification of bacterial isolates}

188 At the sensory rejection time, 22 bacteria were isolated from each storage condition (AIR, VP and MAP). Isolates were selected by picking colonies with various morphologies from plates: 10 colonies from LH and 3 colonies from ELK, STAA,

Caso/VRBG and CHROMagar Pseudomonas. Sixty-six collected isolates were purified twice on Brain Heart Infusion agar (BHI, Biokar). Each isolate was then characterized for Gram reaction with $\mathrm{KOH}$ (Gregersen, 1978), catalase activity by the $3 \% \mathrm{H}_{2} \mathrm{O}_{2}$ method and cytochrome oxidase production by Bactident Oxidase reagent (Merck, Darmstadt, Germany). Extraction of DNA and PCR amplification and identification of the 16S rDNA sequences from purified colonies were monitored as described by Macé et al., 2012.

\subsection{Total bacterial DNA extraction from tuna flesh}

At each sampling date, the 3 independent mother solutions of the triplicate were pooled in equal proportions. Bacterial DNA from $8 \mathrm{ml}$ of this solution was extracted and purified as described by Macé et al., 2012. The concentration and purity of DNA were assessed by optical density using a NanoDrop ND-1000 spectrophotometer (Isogen, De Meern, The Netherlands). DNA samples were stored at $-20^{\circ} \mathrm{C}$ until they were used for Temporal Temperature Gradient Gel Electrophoresis (TTGE) and 16S rDNA amplicon sequencing analyses.

\subsection{Temporal temperature gradient gel electrophoresis analysis}

At each sampling date, bacterial DNA was analyzed by PCR-TTGE. Primers V3P2 and V3P3-GC-Clamp were used to amplify the V3 region of the 16S-rDNA (194 bp) 
211 in the conditions described by Jaffrès et al., 2009. Determination of the size of the

212 PCR products and TTGE analysis were performed as described previously (Jaffrès et

213 al., 2009). Standardization, analysis and comparison of TTGE fingerprints were

214 monitored using BioNumerics Software, version 7.1 (Applied Maths NV,

215 Sint-Martens-Latem, Belgium) as described by Macé et al., 2012.

\subsection{Bacterial 16S rRNA gene amplification and barcoded sequencing}

Bacterial DNA extracted from the tuna matrix at each sampling date was analyzed by Illumina sequencing.

\subsubsection{PCR reaction}

16S rDNA PCR libraries targeting the V1-V3 hypervariable region (minimum amplicon size of 460 bp) were generated. Primers E9-29 and E514-430 (Brosius et al., 1981), specific for bacteria, were selected for their theoretical ability to generate the lowest amplification bias relative to amplification capability/ability among the various bacterial phyla (Wang and Qian, 2009). The oligonucleotide design included the Illumina overhang adapter sequence (Illumina Inc, San Diego, USA). The amplification mix contained $5 \mathrm{U}$ of FastStart high fidelity polymerase (Roche Diagnostics, Basel, Switzerland), 1X enzyme reaction buffer, $200 \mu \mathrm{M}$ dNTPs (Eurogentec, Liège, Belgium), $0.2 \mu \mathrm{M}$ of each primer and $2 \mu \mathrm{l}$ of genomic DNA in a final volume of $25 \mu \mathrm{L}$. Thermocycling conditions consisted of a denaturation step of 3 min at $94^{\circ} \mathrm{C}$, followed by 30 cycles of $30 \mathrm{~s}$ at $94^{\circ} \mathrm{C}, 30 \mathrm{~s}$ at $5^{\circ} \mathrm{C}$, and $1 \mathrm{~min}$ at $72^{\circ} \mathrm{C}$, and a final elongation step of $8 \mathrm{~min}$ at $72^{\circ} \mathrm{C}$. These amplifications were performed on an Ep Master system gradient apparatus (Eppendorf, Hamburg, Germany). The PCR products were checked on $1 \%$ agarose gel electrophoresis and the DNA fragments were purified using AMPure XP beads (Beckman Coulter Inc, California, United 
236 States). A second PCR (index PCR) was performed to attach dual indices and

237 Illumina sequencing adapters using the Nextera XT index kit (Illumina Inc, San

238 Diego, United States) following the manufacturer's recommendations. The quantity of

239 the products was assessed by Picogreen dsDNA quantitation assay (Isogen Life

240 Science). Equal amounts of each of the index PCR products were pooled. This

241 library was quantified and normalized using KAPA SYBR FAST qPCR kit (KAPA

242 BIOSYSTEMS, Boston, United States) following the manufacturer's

243 recommendations.

$244 \quad$ 2.9.2. Illumina sequencing

245 Sequencing was performed with the Illumina MiSeq Sequencer to generate paired

246 sequences $2 \times 300$ bases (Illumina Inc). The MiSeq system provided an instrument

247 secondary analysis using the MiSeq Reporter software V2.5. The metagenomics

248 workflow option must be selected with the $16 \mathrm{~S}$ protocols.

\section{2.9.3. Bioinformatic analysis}

250 Image and data processing for amplicon sequencing was performed using the MiSeq 251 reporter software V2.5 (Illumina Inc). FLASH was used to merge paired overlapped

252 reads of both ends of fragment libraries (Magoc and Salzberg, 2011). The 16S rDNA

253 sequence reads were processed using the MOTHUR software package (Schloss et

254 al., 2009). The quality of all the sequence reads was de-noised using the PyroNoise

255 algorithm implemented in MOTHUR and filtered according to the following criteria:

256 minimal length of $450 \mathrm{bp}$, an exact match to the barcode and 1 mismatch allowed to

257 the proximal primer. Sequences from multiplexed samples were assigned based on

258 the presence of the unique barcodes assigned to each sample. The sequences that

259 passed the quality check were aligned to the SILVA alignment database (Pruesse et

260 al., 2007). These sequences have been deposited at the European Nucleotide 
261

262

263

264

265

266

267

268

269

270

271

272

273

274

275

276

277

278

279

280

281

282

283

284

285

Archive (ENA) under the project accession number PRJEB11823. Chimeric

sequences were detected using the chimera-slayer command included in the MOTHUR package, and potential chimeras were removed (Haas et al., 2011). The sequences were pre-clustered to reduce false operational taxonomic units (OTUs) produced by erroneous sequences. A distance matrix was prepared (distance $=3 \%$ ) and the sequences were clustered to OTUs using the average neighbor algorithm. OTUs representing less than $0.01 \%$ of the total number of reads were considered artifacts and discarded. In the second phase of the experiment, the representative sequences of each OTU were compared with the SILVA microbial database using the Basic Local Alignment Search Tool (BLASTN) (Altschul et al., 1990; Gertz et al., 2006). For each OTU, a standard detailed taxonomic identification was given based on the identity (less than $1 \%$ mismatch with the aligned sequence) and the metadata associated with the best hit (validated bacterial species or not). The genus assignations obtained using MOTHUR and BLAST were compared and noted as unclassified in the case of a mismatch. Each bacterial population identified by metagenetics was analyzed as a proportion of reads, in order to deduce the bacterial flora proportion. The sequences corresponding to mitochondria or chloroplasts were removed prior to analysis. The MOTHUR program was also used to determine the Shannon diversity index, Chao1 and ACE richness indices and coverage estimator at the $3 \%$ distance level.

\subsection{Statistical analysis}

Data were analyzed using the software $R$ (version 2.14.0). Descriptive statistics of means, standard deviation, linear regression, one-way ANOVA and Tukey's HSD post-hoc test were applied. A significance level of $5 \%$ was used. 


\section{Results}

288

289

\subsection{Sensory characteristics of raw tuna}

290

The results of the sensory evaluation of raw yellowfin tuna samples are presented in

291

292

293

294

295

296

297

298

299

300

301

302

303

304

305

306

307

308

309
Table 2. Fresh tuna steak (D0) was mainly characterized by a firm texture with a typical red blood color and a marine odor. After 8 days (D8), all batches received a spoilage score ranging between approximately 2 and 3 and were not significantly different from the fresh sample $(p>0.05)$. However, VP and MAP products presented a slight discoloration of the fish flesh and MAP started to release an unpleasant amine odor and have a slightly greenish color. AIR, VP and MAP steaks were all considered unacceptable after 13 days (spoilage score $\geq 6$ ). Spoilage characteristics as described by the sensory panel were amine, sulfur and pungent off-odors and a bleached, grayish, browned or greenish appearance. The texture of MAP tuna was clearly less firm than AIR and VP samples. Based on these results, it was concluded that VP and MAP do not significantly increase the shelf-life of tuna steaks. This observation may be explained by the fact that these samples were stored at $4 / 8^{\circ} \mathrm{C}$ instead of $0^{\circ} \mathrm{C}$ for AIR products. Although no statis tical difference was observed between samples, MAP slightly accelerated the spoilage process of tuna.

\subsection{Chemical analysis}

The $\mathrm{pH}$ value of raw tuna was very stable during storage, ranging from 5.77 to 5.97 , and no significant difference was observed between the trials $(p>0.05)$ (data not shown). 
310

311

312

313

314

315

316

317

318

319

320

321

322

323

324

325

326

327

328

329

330

331

332

333

334

Figure 1 shows the TVBN and TMA-N results. At day 0, TVBN and TMA-N values were $16.3 \pm 0.6 \mathrm{mg}-\mathrm{N} 100 \mathrm{~g}^{-1}$ and $1.0 \pm 0.1 \mathrm{mg}-\mathrm{N} 100 \mathrm{~g}^{-1}$, respectively. The production of TVBN was very low whatever the storage condition (maximum value of $20.3 \pm 2.0 \mathrm{mg}-\mathrm{N} 100 \mathrm{~g}^{-1}$ ) and there was no significant difference between trials. The maximal TMA-N concentrations were observed at the end of storage for MAP and VP samples reaching $4.6 \pm 1.8 \mathrm{mg}-\mathrm{N} 100 \mathrm{~g}^{-1}$ and $9.0 \pm 1.0 \mathrm{mg}-\mathrm{N} 100 \mathrm{~g}^{-1}$, respectively, contrary to AIR products where no increase was recorded.

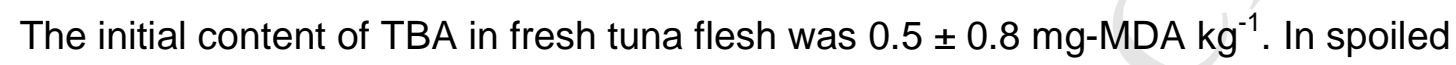
products (day 13), the production reached $2.9 \pm 0.2,0.6 \pm 0.1$ and $6.0 \pm 0.8 \mathrm{mg}-\mathrm{MDA}$ $\mathrm{kg}^{-1}$ for AIR, VP and MAP samples, respectively (data not shown).

At day 0 , the concentration of histamine in tuna flesh was $75.4 \pm 0.5 \mathrm{mg} \mathrm{kg}^{-1}$.

Histamine was fairly stable up to 8 days except for VP samples in which the concentration increased slightly to $83.9 \pm 1.2 \mathrm{mg} \mathrm{kg}^{-1}$. At the sensory rejection time (day 13), histamine concentrations had decreased significantly to reach $25.3 \pm 1.5$, $27.3 \pm 1.4$ and $30.7 \pm 1.9 \mathrm{mg} \mathrm{kg}^{-1}$ in AIR, VP and MAP samples, respectively.

\subsection{Enumeration of the different bacterial groups}

According to the culture-dependent methods, all batches presented a relatively similar bacterial evolution (Figure 2). No difference was observed between TPVC and TMVC. Before tuna packaging (day 0), both counts reached around 3.5 Log CFU g ${ }^{-1}$. A very small increase (not statistically different) was recorded in MAP samples after 8 days (+ $0.5 \mathrm{Log} \mathrm{CFU} \mathrm{g}^{-1}$ ) whereas a growth of 1.5 and $2.0 \mathrm{Log}^{\mathrm{CFU} \mathrm{g}} \mathrm{g}^{-1}$ units was observed in AIR and VP tuna, respectively. At day 13, TPVC and TMVC reached 6-7 Log CFU g ${ }^{-1}$ in all batches. The counts of Enterobacteriaceae and Brochothrix were similar to total counts. Although the initial concentration of LAB was around the 
335

336

337

338

339

340

341

342

343

344

345

346

347

348

349

350

351

352

353

354

355

356

357

358

359

detection threshold $\left(1.7 \mathrm{Log} \mathrm{CFU} \mathrm{g}^{-1}\right)$, they grew rapidly and reached the same level as the other flora. The Pseudomonas count was below the detection threshold till day 10 and then increased to reach $4.6 \pm 0.6,4.8 \pm 0.5$ and $3.6 \pm 0.3 \mathrm{Log} \mathrm{CFU} \mathrm{g}^{-1}$ in AIR, VP and MAP spoiled tuna, respectively. When samples were considered unacceptable by the sensory panel (day 13), all the counts, except Pseudomonas, were around 6 to $7 \mathrm{Log}^{\mathrm{CFU} \mathrm{g}}{ }^{-1}$ (no statistical differences between trials).

In the 3 batches of tuna, the majority of the bacterial isolates were identified as $B$. thermosphacta (55\% of the isolates) and as Pseudomonas spp. (cedrina, fluorescens, fulva, gessardii/libanensis/synxantha, plecoglossicida/monteilii, psychrophila/fragi) (24\%). The others were isolated exclusively from VP and MAP samples and belonged to the Enterobacteriaceae family (Serratia grimesii/liquefaciens/proteamaculans, Hafnia paralvei, Enterobacter asburiae/cancerogenus, Escherichia hermanii) (18\%) and to the LAB group (Carnobacterium divergens, C. maltaromaticum) (3\%).

\subsection{TTGE analysis}

TTGE analysis was used to monitor the evolution of the microbiota composition in yellowfin tuna (AIR, VP and MAP) (Figure 3). The migration level of DNA fragments was compared with those of 14 bacterial species chosen as references; twelve of them isolated from tuna (this study) and 2 others (Lactococcus piscium and Psychrobacter aquaticus) from salmon. As shown in Figure 3, eight different TTGE profiles were found among the Pseudomonas isolates. Fresh tuna (day 0) showed a very weak intensity fingerprint due to a low concentration of bacterial DNA. Among the detected bands, 1 corresponded to $B$. thermosphacta $(k)$ and $3(a$, e and $n)$ were not clearly defined. In addition to the presence of $B$. thermosphacta in all batches at 
360

361

362

363

364

365

366

367

368

369

370

371

372

373

374

375

376

377

378

379

380

381

382

383

384

day 8, AIR and VP profiles revealed additional bands assigned to diverse

Pseudomonas spp. and to LAB for VP products. At the rejection point (day 13), the 3 batches presented a common major band assigned to $B$. thermosphacta. Nevertheless, minor band profiles were different between batches. Pseudomonas spp. diversity was greater in AIR and VP samples than in MAP product. In VP, LAB (L. piscium and C. divergens) and Enterobacteriaceae (H. paralvei) were also present. However, the assignment of bands marked in line e was not clear. In fact, these bands could be assigned to $C$. divergens species, Pseudomonas spp. strain $\mathrm{n} \varepsilon$ or $P$. aquaticus. The lines $\mathrm{a}, \mathrm{g}, \mathrm{m}$ and $\mathrm{n}$ on the figure showed bands that could not be assigned to reference strain profiles and were thus considered unknown.

\subsection{Illumina sequencing analysis}

Table 3 summarizes the number of OTUs as well as the estimation of coverage, richness and diversity of the different tuna samples. Following quality checks, sequencing of total DNA extracted from the 7 samples of tuna (days 0,8 and 13) yielded a total of 48980 bacterial 16S rRNA sequence-read counts (mean value of $5442 \pm 1729$ ) and 721 OTU counts. After 13 days, the number of OTUs decreased in AIR and MAP samples whereas it slightly increased in VP tuna. For each sample, the predicted number of OTUs (estimated by the Chao1 and ACE indices) was close to the number of observed OTUs and the coverage values exceeded $99 \%$. Table 4 details the different bacterial genera/species found in tuna products and Figure 4 represents a synthetic view of the most abundant microbial genera ( $>100$ total reads). At the beginning of the experiment, Rhodanobacter terrae dominated the microbiota of tuna (76\%) but other species such as B. thermosphacta (5\%), Pseudomonas spp. (1\%), Methyloversatilis sp. (0.9\%), Ralstonia sp. (0.7\%), 
385

386

387

388

389

390

391

392

393

394

395

396

397

398

399

400

401

402

403

404

405

406

407

408

409

Psychrobacter spp. (0.5\%) and many unclassified OTUs were detected at low levels

(Table 4). R. terrae disappeared almost completely during storage under the 3 conditions, except in MAP samples at day 8 where it still represented $61 \%$ of the microbial ecosystem. From day 8 until the end of storage, a mix of $B$. thermosphacta ( 65\%) and Pseudomonas spp. ( 30\%) constituted the dominant microbiota of AIR tuna steaks. For MAP products, $B$. thermosphacta represented only $33 \%$ of the microbiota after 8 days of storage but became the major organism at day $13(99.9 \%)$. In VP tuna, despite the fact that $B$. thermosphacta represented $95 \%$ at day 8 , a large diversity was observed after 13 days of packaging (Shannon index $=2.08$ ). Thus, several different species dominated the microbiota, which was composed of $B$. thermosphacta (36\%), Enterobacteriaceae (29\%), LAB (21\%), Pseudomonas (3\%) and many unclassified OTUs with a low occurrence. Enterobacteriaceae were mainly composed of $H$. paralvei and LAB with the genus Lactococcus (including L. piscium) and Carnobacterium (including C. maltaromaticum), but also with Leuconostoc gelidum and Lactobacillus crispatus (Table 4). Among Pseudomonas, the species collierea, deceptionensis, psychrophila, syncyanea and teatrolens were found but this genus comprises more than 200 species and many OTUs could not be clearly identified. Unclassified bacteria represented less than $5 \%$ of sample reads, except for fresh tuna and VP samples at day 13 which were equal to $12 \%$ and $7 \%$, respectively.

\section{Discussion}

In the present study, quality changes in tropical T. albacares were analyzed. The choice of the gas composition for the MAP product was based on the study of Yesudhason et al., 2010 in which an atmosphere of $70 \% \mathrm{CO}_{2}-30 \% \mathrm{O}_{2}$ extended the shelf-life of steaks of a tropical scombroid species (Scomberomorus commerson) by 
410

411

412

413

414

415

416

417

418

419

420

421

422

423

424

425

426

427

428

429

430

431

432

433

434

10 days. Based on this result and previous researches (Emborg et al., 2005; Goulas and Kontominas, 2007; Lalitha et al., 2005; Özogul et al., 2004; Ravi Sankar et al., 2008; Ruiz-Capillas and Moral, 2001; Ruiz-Capillas and Moral, 2005), we anticipated an extension of the shelf-life of packed products by several days and the initial sampling plan was designed accordingly. Finally, all batches were rejected by panelists after 13 days of storage and just 3 data points were collected for VP and MAP products. Nonetheless, in our study, samples were not stored at the same temperature (AIR at $0^{\circ} \mathrm{C}, \mathrm{VP}$ and MAP at $4 / 8^{\circ} \mathrm{C}$ ) and $\mathrm{t}$ his difference may have an influence on shelf-life (Du et al., 2001; Du et al., 2002) and may reduce the preservative effect of packaging (Sivertsvik et al., 2002).

The fact that the initial TVBN concentration was higher than that usually found in fresh fish was regularly observed for pelagic fish (Edirisinghe et al., 2007; El

Marrakchi et al., 1990; Malle et al., 1983; Pérez-Villarreal and Pozo, 1990; Surendran et al., 1989). Although some significant increases were noted at day 13 , none of the batches exceeded the acceptability limit of $30-35 \mathrm{mg}-\mathrm{N} 100 \mathrm{~g}^{-1}$ for TVBN and 10-15 mg-N $100 \mathrm{~g}^{-1}$ for TMA-N, indicating that these indices are not reliable to characterize the spoilage of yellowfin tuna (Huss, 1996). The TBA index reflects a higher oxidation of tuna lipids in samples packed with oxygen (MAP and AIR) and at day 13, MAP products exceeded the limit reported in the literature, which is between 5 and 8 mg-MDA kg ${ }^{-1}$ (Beltran and Moral, 1990; Nunes et al., 1992). However, the sensory panel did not detect any rancid off-odor.

A high free histidine content is generally found on yellowfin tuna flesh (Emborg et al., 2005) and may rapidly lead to the synthesis of a large amount of histamine causing HFP. Freshly caught yellowfin tuna generally contain 10 to $30 \mathrm{mg} \mathrm{kg}^{-1}$ of histamine (Guizani et al., 2005; Sika et al., 2014; Widiastuti et al., 2013). In the present study, 
435 the initial histamine amount was high $(\approx 80 \mathrm{ppm})$. At day 0 , none of the main bacterial

436 species producers (i.e. Photobacterium phosphoreum, Morganella morganii,

437 Raoultella spp., ...) was detected by culture-independent techniques. However, the production of histamine from $R$. terrae, the main bacterium found in fresh tuna, is unknown. $R$. terrae is a gram-negative bacteria belonging to the Xanthomonadaceae family, first isolated from soil from a ginseng field in South Korea and described by Weon et al., 2007. To our knowledge, species from the Rhodanobacter genus have never been found in marine products. No strains could be isolated from our samples with the culture conditions used. Further studies are necessary to verify whether this species is commonly found in $T$. albacares and to evaluate its role in spoilage and histamine production. Thereafter, the histamine concentration dropped while the TVC reached a level of $10^{6} \mathrm{CFU} \mathrm{g}^{-1}$, as observed by Guizani et al., 2005. Previous studies suggest a proliferation of histamine-decomposing bacteria (Ababouch et al., 1996; López-Sabater et al., 1996; Sato et al., 1994; Silva et al., 1998) but this has never been experimentally confirmed in tuna. Bacillus, Staphylococcus, LAB and other strains are able to oxidize biogenic amines such as histamine (Alvarez and MorenoArribas, 2014).

Regarding culture-dependent results, TMVC and TPVC had a similar increasing trend, as found by Mohan et al., 2010. After 13 days, total microbial counts reached 6-7 Log CFU g ${ }^{-1}$, which is considered the limit of acceptability for freshwater and marine fish (ICMSF, 1986). Initially, a majority (93\%) of gram-negative bacteria was detected. The top five genera of fresh tuna were Rhodanobacter, Brochothrix, Pseudomonas, Methyloversatilis and Ralstonia. Chaillou et al., 2014 studied the bacterial diversity of various meat and seafood products by pyrosequencing. At day 459 0, except for Brochothrix, the tuna ecosystem differs widely from cod and salmon, 
460

461

462

463

464

465

466

467

468

469

470

471

472

473

474

475

476

477

478

479

480

481

482

483

484

possibly due to the composition of the flesh or the environmental parameters, and

particularly to the fact that cod and salmon originate in temperate water.

PCR-TTGE and Illumina sequencing methods revealed a selection of specific

bacteria during spoilage. Under AIR at $0^{\circ} \mathrm{C}, B$. thermosphacta and Pseudomonas

spp. became dominant. $B$. thermosphacta is a spoiling bacteria often isolated in MAP

poultry, meat and seafood (Hovda et al., 2007b; Jaffrès et al., 2009; Kakouri and

Nychas, 1994; Koutsoumanis and Nychas, 1999; Mamlouk et al., 2012; Mejlholm et

al., 2005; Nychas et al., 2008) or in lightly preserved VP products (Olofsson et al., 2007), but more rarely from fish stored under air (Noseda et al., 2012). On the contrary, Pseudomonas spp., particularly $P$. fragi, is often reported to be responsible for sweet and fruity off-odors in fish flesh stored under air (Gennari et al., 1999; Gram and Huss, 1996; Hovda et al., 2007a; Hozbor et al., 2006; Koutsoumanis and Nychas, 1999; Miller et al., 1973; Ola and Oladipo, 2004; Parlapani et al., 2015a; Parlapani et al., 2015b; Parlapani and Boziaris, 2016; Ravi Sankar et al., 2008). In agreement with previous studies (Lalitha et al., 2005; Lopez-Galvez et al., 1995; Özogul et al., 2004; Ravi Sankar et al., 2008), $\mathrm{CO}_{2}$ has a bacteriostatic effect which delays the growth of various flora, and Pseudomonas are particularly sensitive to $\mathrm{CO}_{2}$ (Ehsani and Jasour, 2012; Koutsoumanis et al., 2000). This probably explains why MAP products presented the lowest bacterial diversity, with $B$. thermosphacta representing over $98 \%$ of the spoiled products. In VP tuna, B. thermosphacta dominated at day 8 but after 13 days, Enterobacteriaceae and LAB represented a high proportion of the microbiota. Vacuum is well known to prevent the growth of strict aerobic bacteria, such as Pseudomonas and Rhodanobacter, and to favor LAB (Leroi, 2010). Finally, despite the fact that some differences in the evolution of the tuna microbiota were observed, the 3 batches had the same shelf-life. 
In conclusion, the results of PCR-TTGE and Illumina sequencing analyses are similar and provide data on the bacterial spoilage of yellowfin tuna flesh. Knowledge about the microbial changes and quality deterioration is important for assessing shelf-life and could contribute to constructing predictive models. However, supplementary research is needed to characterize the spoilage potential of the bacteria isolated from tuna and develop rapid quality control methods for the local fishing sector.

\section{Acknowledgements}

This research was financially supported by the Martinique Region and the European

Fisheries Fund. The authors thank the staff of the Quality Partner company,

particularly M. Laurent Delhalle, for their valued contribution in processing Illumina sequencing data, and Carol Robins for the English language editing of the manuscript.

\section{Ababouch, L.H., Souibri, L., Rhaliby, K., Ouahdi, O., Battal, M., Busta, F.F., 1996. Quality changes in sardines (Sardina pilchardus) stored in ice and at ambient temperature. Food Microbiology 13, 123-132.}

AFNOR, 2010. NF V 01-003. Lignes directives pour la réalisation de tests de vieillissement microbiologique - Aliments périssables et très périssables réfrigérés. Hygiène des aliments

Altschul, S.F., Gish, W., Miller, W., Myers, E.W., Lipman, D.J., 1990. Basic local alignment search tool. Journal of Molecular Biology 215, 403-410.

Alvarez, M.A., Moreno-Arribas, M.V., 2014. The problem of biogenic amines in fermented foods and the use of potential biogenic amine-degrading microorganisms as a solution. Trends in Food Science \& Technology 39, 146155.

Ashie, I.N.A., Smith, J.P., Simpson, B.K., 1996. Spoilage and shelf $\square$ life extension of fresh fish and shellfish. Critical Reviews in Food Science and Nutrition 36 (1\&2), $87-121$. 
Beltran, A., Moral, A., 1990. Gas chromatographic estimation of oxidative deterioration in sardine during frozen storage. Lebens-Wissen Technology 23 , 499-504.

Brosius, J., Dull, T.J., Sleeter, D.D., Noller, H.F., 1981. Gene organization and primary structure of a ribosomal RNA operon from Escherichia coli. Journal of Molecular Biology 148, 107-127.

Cakli, S., Kilinc, B., Dincer, T., Tolasa, S., 2006. Comparison of the shelf lifes of map and vacuum packaged hot smoked rainbow trout (Onchoryncus mykiss). European Food Research and Technology 224, 19-26.

Chaillou, S., Chaulot-Talmon, A., Caekebeke, H., Cardinal, M., Christieans, S., Denis, C., Desmonts, M.H., Dousset, X., Feurer, C., Hamon, E., Joffraud, J.J., La Carbona, S., Leroi, F., Leroy, S., Lorre, S., Macé, S., Pilet, M.F., Prévost, H., Rivollier, M., Roux, D., Talon, R., Zagorec, M., Champomier-Vergès, M.C., 2014. Origin and ecological selection of core and food-specific bacterial communities associated with meat and seafood spoilage. International Society for Microbial Ecology 1 (14), 1751-7362.

Conway, E.J., Byrne, A., 1933. An absorption apparatus for the micro-determination of certain volatile substances: The micro-determination of ammonia. Biochemical Journal 27, 419.

Cramer, J.L., Nakamura, R.M., Dizon, A.E., Ikehara, W.N., 1981. Burnt tuna: conditions leading to rapid deterioration in the quality of raw tuna. Marine Fisheries Review 43 (6), 12-16.

Dainty, R.H., 1996. Chemical/biochemical detection of spoilage. International journal of food microbiology 33, 19-33.

Dalgaard, P., Gram, L., Huss, H.H., 1993. Spoilage and shelf-life of cod fillets packed in vacuum or modified atmospheres. International journal of food microbiology 19, 283-294.

Du, W.X., Kim, J., Cornell, J.A., Huang, T.S., Marshall, M.R., Wei, C.I., 2001. Microbiological, sensory, and electronic nose evaluation of yellowfin tuna under various storage conditions. Journal of Food Protection 64 (12), 2027-2036.

Du, W.X., Lin, C.M., Phu, A.T., Cornell, J.A., Marshall, M.R., Wei, C.I., 2002. Development of biogenic amines in yellowfin tuna (Thunnus albacares): Effect of storage and correlation with decarboxylase-positive bacterial flora. Journal of Food Science 67 (1), 292-301.

Duflos, G., 2009. Le risque histamine dans les produits de la pêche. Bulletin de l'académie vétérinaire de France Tome 162 N\%3, 241-245.

Edirisinghe, R.K.B., Graham, A.J., Taylor, S.J., 2007. Characterisation of the volatiles of yellowfin tuna (Thunnus albacares) during storage by solid phase 
microextraction and GC-MS and their relationship to fish quality parameters. International Journal of Food Science and Technology 42, 1139-1147.

Ehsani, A., Jasour, M.S., 2012. Microbiological properties and biogenic amines of whole Pike-Perch (Sander Lucioperca, Linnaeus 1758): a perspective on fish safety during postharvest handling practices and frozen storage. Journal of Food Science 77 (12), M664-M668.

El Marrakchi, A.E., Bennour, M., Bouchriti, N., Hamama, A., Tagafatit, H., 1990. Sensory, chemical, and microbiological assessments of Moroccan sardines (Sardina pilchardus) stored in ice. Journal of Food Protection 53, 600-605.

Emborg, J., Laursen, B.G., Dalgaard, P., 2005. Significant histamine formation in tuna (Thunnus albacares) at $2^{\circ} \mathrm{C}$-effect of vacuum-and modified atmospherepackaging on psychrotolerant bacteria. International journal of food microbiology 101, 263-279.

FAO, 2014. The state of world fisheries and aquaculture 2014. Rome. 223 pp. URL: http://www.fao.org/3/a-i3720e/index.html.

Ferrario, C., Pegollo, C., Ricci, G., Borgo, F., Fortina, M.G., 2012. PCR detection and identification of histamine $\square$ forming bacteria in filleted tuna fish samples. Journal of Food Science 77 (2), M115-M120.

Frank, H.A., Baranowski, J.D., Chongsiriwatana, M., Brust, P.A., Premaratne, R.J., 1985. Identification and decarboxylase activities of bacteria isolated from decomposed mahimahi (Coryphaena hippurus) after incubation at 0 and $32^{\circ} \mathrm{C}$. International journal of food microbiology 2 (6), 331-340.

Galaviz-Silva, L., Goméz-Anduro, G., Molina-Garza, Z.J., Ascencio-Valle, F., 2009. Food safety issues and microbiology of fish and shellfish, in: Heredia N, Wesley,I., Garcia S (Eds.), Microbiologically Safe Foods. John Wiley \& Son, Hoboken, pp. 227-254.

Gennari, M., Tomaselli, S., Cotrona, V., 1999. The microflora of fresh and spoiled sardines (Sardina pilchardus) caught in Adriatic (Mediterranean) Sea and stored in ice. Food Microbiology 16, 15-28.

Gertz, E.M., Yu, Y.K., Agarwala, R., Schaffer, A.A., Altschul, S.F., 2006. Composition-based statistics and translated nucleotide searches: improving the TBLASTN module of BLAST. BMC biology 7, 4-41.

Giacomazzi, S., Leroi, F., L'Henaff, C., Joffraud, J.J., 2004. rpoB $\square$ PCR amplified gene and temporal temperature gradient gel electrophoresis: a rapid tool to analyse bacterial strains representative of cold $\square$ smoked salmon microflora. Letters in applied microbiology 38, 130-134.

Gill, T.A., Thompson, J.W., Gould, S., Sherwood, D., 1987. Characterization of quality deterioration in yellowfin tuna. Journal of Food Science 52 (3), 580-583. 
Goulas, A.E., Kontominas, M.G., 2007. Effect of modified atmosphere packaging and vacuum packaging on the shelf-life of refrigerated chub mackerel (Scomber japonicus): biochemical and sensory attributes. European Food Research and Technology 224, 545-553.

Gram, L., Huss, H.H., 2000. Fresh and processed fish and shellfish. The microbiological safety and quality of food 1, 472-506.

Gram, L., Huss, H.H., 1996. Microbiological spoilage of fish and fish products. International journal of food microbiology 33, 121-137.

Gram, L., Ravn, L., Rasch, M., Bruhn, J.B., Christensen, A.B., Givskov, M., 2002. Food spoilage-interactions between food spoilage bacteria. International journal of food microbiology 78, 79-97.

Gregersen, T., 1978. Rapid method for distinction of Gram-negative from Grampositive bacteria. European Journal of Applied Microbiology and Biotechnology 5, 123-127.

Guizani, N., Al-Busaidy, M.A., Al-Belushi, I.M., Mothershaw, A., Rahman, M.S., 2005. The effect of storage temperature on histamine production and the freshness of yellowfin tuna (Thunnus albacares). Food Research International 38, 215-222.

Haas, B.J., Gevers, D., Earl, A.M., Feldgarden, M., Ward, D.V., Giannoukos, G., Ciulla, D., Tabbaa, D., Highlander, S.K., Sodergren, E., Methe, B., De Santis, T.Z., Petrosino, J.F., Knight, R., Birren, B.W., 2011. Chimeric 16S rRNA sequence formation and detection in Sanger and 454-pyrosequenced PCR amplicons. Genome research 21, 494-504.

Hovda, M.B., Lunestad, B.T., Sivertsvik, M., Rosnes, J.T., 2007a. Characterisation of the bacterial flora of modified atmosphere packaged farmed Atlantic cod (Gadus morhua) by PCR-DGGE of conserved $16 \mathrm{~S}$ rRNA gene regions. International Journal of Food Microbiology 117, 68-75.

Hovda, M.B., Sivertsvik, M., Lunestad, B.T., Lorentzen, G., Rosnes, J.T., 2007b. Characterisation of the dominant bacterial population in modified atmosphere packaged farmed halibut (Hippoglossus hippoglossus) based on 165 rDNADGGE. Food Microbiology 24, 362-371.

Hozbor, M.C., Saiz, A.I., Yeannes, M.I., Fritz, R., 2006. Microbiological changes and its correlation with quality indices during aerobic iced storage of sea salmon (Pseudopercis semifasciata). LWT 39, 99-104.

Hungerford, J.M., 2010. Scombroid poisoning: a review. Toxicon 56, 231-243.

Huss, H.H., 1996. Assurance de la qualité des produits de la mer. FAO 334, 13-17.

ICMSF, 1986. Microorganisms in Foods. 2. Sampling for microbiological analysis: Principles and specific applications. 2nd ed. Toronto: University of Toronto press. 
Jaffrès, E., Sohier, D., Leroi, F., Pilet, M.F., Prévost, H., Joffraud, J.J., Dousset, X., 2009. Study of the bacterial ecosystem in tropical cooked and peeled shrimps using a polyphasic approach. International journal of food microbiology 131, 2029.

Joffraud, J.J., Leroi, F., Roy, C., Berdague, J.L., 2001. Characterisation of volatile compounds produced by bacteria isolated from the spoilage flora of cold-smoked salmon. International journal of food microbiology 66, 175-184.

Kakouri, A., Nychas, G.J.E., 1994. Storage of poultry meat under modified atmospheres or vacuum packs: possible role of microbial metabolites as indicator of spoilage. Journal of Applied Bacteriology 76 (2), 163-172.

Kanki, M., Yoda, T., Tsukamoto, T., Baba, E., 2007. Histidine decarboxylases and their role in accumulation of histamine in tuna and dried saury. Applied and Environmental Microbiology 73 (5), 1467-1473.

Koutsoumanis, K., Nychas, G.J.E., 1999. Chemical and sensory changes associated with microbial flora of Mediterranean boque (Boops boops) stored aerobically at $0,3,7$, and ${ }^{\circ} 0^{\circ} \mathrm{C}$. Applied and Environmental Microb iology 65 (2), 698-706.

Koutsoumanis, K.P., Taoukis, P.S., Drosinos, E.H., Nychas, G.J.E., 2000. Applicability of an Arrhenius model for the combined effect of temperature and $\mathrm{CO}_{2}$ packaging on the spoilage microflora of fish. Applied and Environmental Microbiology 66 (8), 3528-3534.

Lalitha, K.V., Sonaji, E.R., Manju, S., Jose, L., Gopal, T.K.S., Ravisankar, C.N., 2005. Microbiological and biochemical changes in pearl spot (Etroplus suratensis Bloch) stored under modified atmospheres. Journal of applied microbiology 99, 1222-1228.

Lee, S., Joo, S.T., Alderton, A.L., Hill, D.W., Faustman, C., 2003. Oxymyoglobin and lipid oxidation in yellowfin tuna (Thunnus albacares) loins. Journal of Food Science 68 (5), 1664-1668.

Lehane, L., Olley, J., 2000. Histamine fish poisoning revisited. International journal of food microbiology 58, 1-37.

Leroi, F., 2010. Occurrence and role of lactic acid bacteria in seafood products. Food Microbiology 27 (6), 698-709.

Leroi, F., Cornet, J., Chevalier, F., Cardinal, M., Coeuret, G., Chaillou, S., Joffraud, J., 2015. Selection of bioprotective cultures for preventing cold-smoked salmon spoilage. International journal of food microbiology 213, 79-87.

Liston, J., 1980. Microbiology in fishery science, in: Connell J J (Ed.), Advances in fishery science and technology. Fishing News Books Ltd, Farnham, England, pp. 138-157. 
690

Lopez-Galvez, D., De La Hoz, L., Ordonez, J.A., 1995. Effect of carbon dioxide and oxygen enriched atmospheres on microbiological and chemical changes in refrigerated tuna (Thunnus alalunga) steaks. Journal of Agricultural and Food Chemistry 43, 483-490.

López-Sabater, E.I., Rodríguez-Jerez, J.J., Hernádez-Herrero, M., Roig-Sagués, A.X., Mora-Ventura, M.T., 1996. Sensory quality and histamine formation during controlled decomposition of tuna (Thunnus thynnus). Journal of Food Protection® 59, 167-174.

Lukton, A., Olcott, H.S., 1958. Content of free imidazole compounds in the muscle tissue of aquatic animals. Journal of Food Science 23 (6), 611-618.

Macé, S., Cornet, J., Chevalier, F., Cardinal, M., Pilet, M., Dousset, X., Joffraud, J., 2012. Characterisation of the spoilage microbiota in raw salmon (Salmo salar) steaks stored under vacuum or modified atmosphere packaging combining conventional methods and PCR-TTGE. Food Microbiology 30 (1), 164-172.

Magoc, T., Salzberg, S.L., 2011. FLASH: fast length adjustment of short reads to improve genome assemblies. Bioinformatics 27, 2957-2963.

Malle, P., Nowogrocki, G., Tailliez, R., 1983. Correlation entre l'indice d'alteration et l'azote basique volatil total pour divers poissons marins. Sciences des Aliments 3, 311-322.

Mamlouk, K., Macé, S., Guilbaud, M., Jaffrès, E., Ferchichi, M., Prévost, H., Pilet, M.F., Dousset, X., 2012. Quantification of viable Brochothrix thermosphacta in cooked shrimp and salmon by real-time PCR. Food Microbiology 30, 173-179.

Mejlholm, O., Bøknæs, N., Dalgaard, P., 2005. Shelf life and safety aspects of chilled cooked and peeled shrimps (Pandalus borealis) in modified atmosphere packaging. Journal of applied microbiology 99, 66-76.

Miller, A., Scanlan, R.A., Lee, J.S., Libbey, L.M., 1973. Identification of the volatile compounds produced in sterile fish muscle (Sebastes melanops) by Pseudomonas fragi. Applied Microbiology 25, 952-955.

Mohan, C.O., Ravishankar, C.N., Gopal, T.S., Lalitha, K.V., Kumar, K.A., 2010. Effect of reduced oxygen atmosphere and sodium acetate treatment on the microbial quality changes of seer fish (Scomberomorus commerson) steaks stored in ice. Food Microbiology 27, 526-534.

Noseda, B., Islam, M.T., Eriksson, M., Heyndrickx, M., De Reu, K., Van Langenhove, H., Devlieghere, F., 2012. Microbiological spoilage of vacuum and modified atmosphere packaged Vietnamese Pangasius hypophthalmus fillets. Food Microbiology 30 (2), 408-419.

Nunes, L.M., Batista, I., De Campos, M.R., 1992. Physical, chemical and sensory analysis of sardine (Sardina pilchardus) stored in ice. Journal of the science of food and agriculture 59, 37-43. 
Nychas, G.J.E., Skandamis, P.N., Tassou, C.C., Koutsoumanis, K.P., 2008. Meat spoilage during distribution. Meat Science 78, 77-89.

Ola, J.B., Oladipo, A.E., 2004. Storage life of croaker (Pseudotholitus senegalensis) in ice and ambient temperature. African Journal of Biomedical Research 7, 1317.

Olofsson, T.C., Ahrné, S., Molin, G., 2007. The bacterial flora of vacuum-packed cold-smoked salmon stored at ${ }^{\circ} \mathrm{C}$, identified by direct $16 \mathrm{~S}$ rRNA gene analysis and pure culture technique. Journal of applied microbiology 103, 109-119.

Özogul, F., Polat, A., Özogul, Y., 2004. The effects of modified atmosphere packaging and vacuum packaging on chemical, sensory and microbiological changes of sardines (Sardina pilchardus). Food Chemistry 85, 49-57.

Parlapani, F.F., Kormas, K.A., Boziaris, I.S., 2015a. Microbiological changes, shelf life and identification of initial and spoilage microbiota of sea bream fillets stored under various conditions using 16S rRNA gene analysis. Journal of the Science of Food and Agriculture 95 (12), 2386-2394.

Parlapani, F.F., Verdos, G.I., Haroutounian, S.A., Boziaris, I.S., 2015b. The dynamics of Pseudomonas and volatilome during the spoilage of gutted sea bream stored at $2^{\circ} \mathrm{C}$. Food Control 55, 257-265.

Parlapani, F.F., Boziaris, I.S., 2016. Monitoring of spoilage and determination of microbial communities based on 16S rRNA gene sequence analysis of whole sea bream stored at various temperatures. LWT - Food Science and Technology $66,553-559$.

Pérez-Villarreal, B., Pozo, R., 1990. Chemical composition and ice spoilage of albacore (Thunnus alalunga). Journal of Food Science 55 (3), 678-682.

Poulter, R.G., Curran, C.A., Disney, J.G., 1981. Chill storage of tropical and temperate water fish - differences and similarities, Proceedings of the II-Rconference on advances in the refrigerated treatment of fish, 1981-4. Boston (USA), pp. 111-124.

Pruesse, E., Quast, C., Knittel, K., Fuchs, B.M., Ludwig, W., Peplies, J., Glockner, F.O., 2007. SILVA: a comprehensive online resource for quality checked and aligned ribosomal RNA sequence data compatible with ARB. Nucleic acids research 35, 7188-7196.

Rachman, C., Fourrier, A., Sy, A., De La Cochetiere, Marie France, Prevost, H., Dousset, X., 2004. Monitoring of bacterial evolution and molecular identification of lactic acid bacteria in smoked salmon during storage. Le Lait 84 (1-2), 145154.

Ravi Sankar, C.N., Lalitha, K.V., Jose, L., Manju, S., Gopal, T.K.S., 2008. Effect of packaging atmosphere on the microbial attributes of pearlspot (Etroplus suratensis Bloch) stored at 0-2 . Food Microbiology 25, 518- 528. 
Reddy, N.R., Armstrong, D.J., Rhodehamel, E.J., Kautter, D.A., 1992. Shelf-life extension and safety concerns about fresh fishery products packaged under modified atmospheres: a review. Journal of Food Safety 12, 87-118.

Reynal,L., Demanèche, S., Guyader, O., Bertrand, J., Berthou, P., Dromer, C., Bruneau, M., Bellanger, M., Merrien, C., Guegan, F., Lespagnol, P., Pitel, M., Jézéquel, M., Leblond, E., Daurès, F., 2011. Projet pilote du Système d'Informations Halieutiques (SIH) Martinique (2007-2010). Premières données sur la pêche en Martinique (2009-2010). Ifremer-SIH-2013/06/30, http://archimer.ifremer.fr/doc/00156/26762/, 176 p.

Ruiz-Capillas, C., Moral, A., 2001. Residual effect of $\mathrm{CO}_{2}$ on hake (Merluccius merluccius L.) stored in modified and controlled atmospheres. European Food Research and Technology 212, 413-420.

Ruiz-Capillas, C., Moral, A., 2005. Sensory and biochemical aspects of quality of whole bigeye tuna (Thunnus obesus) during bulk storage in controlled atmospheres. Food Chemistry 89, 347-354.

Saito, H., Ishihara, K., Murase, T., 1996. Effect of prey fish lipids on the docosahexaenoic acid content of total fatty acids in the lipid of Thunnus albacares yellowfin tuna. Bioscience, biotechnology, and biochemistry 60 (6), 962-965.

Sato, T., Fujii, T., Masuda, T., Okuzumi, M., 1994. Changes in number of histaminemetabolic bacteria and histamine content during storage of common mackerel. Fisheries science 60 (3), 299-302.

Schloss, P.D., Westcott, S.L., Ryabin, T., Hall, J.R., Hartmann, M., Hollister, E.B., Lesniewski, R.A., Oakley, B.B., Parks, D.H., Robinson, C.J., Sahl, J.W., Stres, B., Thallinger, G.G., Van Horn, D.J., Weber, C.F., 2009. Introducing mothur: open-source, platform-independent, community-supported software for describing and comparing microbial communities. Applied and Environmental Microbiology 75, 7537-7541.

Selli, S., Rannou, C., Prost, C., Robin, J., Serot, T., 2006. Characterization of aromaactive compounds in rainbow trout (Oncorhynchus mykiss) eliciting an off-odor. Journal of Agricultural and Food Chemistry 54, 9496-9502.

Shewan, J.M., 1971. The microbiology of fish and fishery products-a progress report. Journal of applied bacteriology 34 (2), 299-315.

Sika, A.E., Ake Assi, Y., Koffi-Nevry, R., Biego, H., 2014. Histamine contents in tuna loins (Thunnus sp.) produced in côte d'ivoire and its relation with bacterial load. International Journal of Science and Research 3 (6), 2347-2351.

Silva, C.C.G., Da Ponte, D.J.B., Enes Dapkevicius, M.L.N., 1998. Storage temperature effect on histamine formation in big eye tuna and skipjack. Journal of Food Science 63 (4), 644-647. 
Sivertsvik, M., Jeksrud, W.K., Rosnes, J.T., 2002. A review of modified atmosphere packaging of fish and fishery products - significance of microbial growth, activities and safety. International Journal of Food Science and Technology 37, 107-127.

Staruszkiewicz, W.F., Barnett, J.D., Rogers, P.L., Benner, R.A.J., Wong, L.L., Cook, J., 2004. Effects of on-board and dockside handling on the formation of biogenic amines in mahimahi (Coryphaena hippurus), skipjack tuna (Katsuwonus pelamis), and yellowfin tuna (Thunnus albacares). Journal of Food Protection 67, 134-141.

Sumner, J.L., Gorczyca, E., Cohen, D., Brady, P., 1984. Do fish from tropical waters spoil less rapidly in ice than fish from temperate waters? Food Technology in Australia 36 (7), 328-334.

Surendran, P., Joseph, J., Shenoy, A., Perigreen, P., Mahadeva K, Gopakumar, K., 1989. Studies on spoilage of commercially important tropical fishes under iced storage. Fisheries research 7, 1-9.

Susanto, E., Agustini, T.W., Ritanto, E.P., Dewi, E.N., Swastawati, F., 2011. Changes in oxidation and reduction potential $(\mathrm{Eh})$ and $\mathrm{pH}$ of tropical fish during storage. Journal of Coastal Development 14 (3), 223-234.

Taylor, S.L., Eitenmiller, R.R., 1986. Histamine food poisoning: toxicology and clinical aspects. CRC critical reviews in toxicology 17 (2), 91-128.

Van Spreekens, K.J.A., 1974. The suitability of a modification of Long and Hammer's medium for the enumeration of more fastidious bacteria from fresh fishery products. Archiv für Lebensmittelhygiene 25 (10), 213-219.

Vyncke, W., 1970. Direct determination of the thiobarbituric acid value in trichloracetic acid extracts of fish as a measure of oxidative rancidity. FetteSeifen-Anstrichmit tel 72, 1084-1087.

Wang, Y., Qian, P.Y., 2009. Conservative fragments in bacterial 16S rRNA genes and primer design for $16 \mathrm{~S}$ ribosomal DNA amplicons in metagenomic studies. Plos one 4, e7401.

Weon, H.Y., Kim, B.Y., Hong, S.B., Jeon, Y.A., Kwon, S.W., Go, S.J., Koo, B.S., 2007. Rhodanobacter ginsengisoli sp. nov. and Rhodanobacter terrae sp. nov., isolated from soil cultivated with Korean ginseng. International Journal of Systematic and Evolutionary Microbiology 57, 2810-2813.

Widiastuti, I., Putro, S., Fardiaz, D., Trilaksani, W., Inaoka, T., 2013. Changes in freshness of steak and loin tuna (Thunnus albacares) during 15 day-chilled storage. Journal of Fisheries and Aquatic Science 8 (2), 367-377.

Yesudhason, P., Gopal, T.K.S., Ravishankar, C.N., Lalitha, K.V., Kumar, A., 2010. Effect of potassium sorbate and modified atmosphere packaging on the shelf-life 

extension of seer fish (Scomberomorus commerson) steaks during iced storage. Journal of Food Biochemistry 34 (2), 399-424.

822 
824

825

826

827

828

829

830

831

832

833

834

835

836

837

838

839

840

841

842

843

844

845

846

847

848

849

850

851

852

853

854

855

\section{List of figures}

Figure 1: TVBN (light) and TMA-N (dark) production (mg-N $100 \mathrm{~g}^{-1}$ ) in raw tuna flesh packed under air at $0^{\circ} \mathrm{C}(\mathrm{AIR})$, vacuum packaging at $4 / 8^{\circ} \mathrm{C}(\mathrm{VP})$ and modified atmosphere packaging at $4 / 8^{\circ} \mathrm{C}$ (MAP) after 0,8 and 13 days. Values with different superscript letters are significantly different $(p>0.05)$. Bars represent standard deviations.

Figure 2: Changes in spoiling bacteria (Log CFU g $\left.{ }^{-1}\right)$ during air storage at $0^{\circ} \mathrm{C}(\square)$, $4 / 8^{\circ} \mathrm{C}$ vacuum packaging $(\circ)$ and modified atmosphere packaging $(\diamond)$ of yellowfin tuna steaks. 1: total psychrotrophic viable counts (TPVC), total mesophilic viable counts (TMVC); 2: Brochothrix (Bx), Pseudomonas (Ps); 3: Enterobacteriaceae (Ent), lactic acid bacteria (LAB).

Figure 3: TTGE profiles of the 16S rDNA gene V3 regions obtained by PCR amplification from total bacterial DNA extraction of fresh tuna (D0) and tuna flesh packed under air at $0^{\circ} \mathrm{C}(\mathrm{AIR})$, vacuum packaging at $4 / 8^{\circ} \mathrm{C}(\mathrm{VP})$ and modified atmosphere packaging at $4 / 8^{\circ} \mathrm{C}$ (MAP) at each date of sampling (D). Lanes Brochothrix thermosphacta; Hafnia paralvei; Carnobacterium divergens; Carnobacterium maltaromaticum; Pseudomonas spp. 1-8, Lactococcus piscium, Psychrobacter aquaticus: profiles of pure strain. Assignment of bacterial reference strain profiles to PCR-TTGE bands obtained from tuna matrix: b, L. piscium; c, Pseudomonas sp. 2; d, Pseudomonas sp. 5; e, C. divergens or Pseudomonas sp. 6 or P. aquaticus; f, Pseudomonas sp. 8; h, Pseudomonas sp. 3; i, H. paralvei; j, Pseudomonas sp. 3; k, B. thermosphacta; I, B. thermosphacta; a, g, m and n, unassigned bands with the bacterial reference strain profiles, considered unknown.

Figure 4: Relative abundance (\%) at the genus level (> 100 reads) based on the classification of partial 16S rDNA sequences of bacteria from fresh tuna (D0) and tuna packed under air at $0^{\circ} \mathrm{C}$ (AIR), vacuum at $4 / 8^{\circ} \mathrm{C}$ (VP) and modified atmosphere at $4 / 8^{\circ} \mathrm{C}$ (MAP) at each date of sampling (D).Others comprise bacterial genera with less than 100 reads. Unclassified represents genera/species not assigned OTUs. 
856 Table 1: Aromatic molecules used for the odor training session of panelists.

\begin{tabular}{lll}
\hline Aromatic molecules & PubChem CID & Related odor \\
\hline $\begin{array}{l}\text { Diacetyl } \\
\text { butane-2,3-dione }\end{array}$ & 650 & Rancid butter \\
\hline $\begin{array}{l}\text { Octenol } \\
\text { oct-1-en-3-ol }\end{array}$ & 18827 & Mushroom \\
\hline $\begin{array}{l}\text { Pyrrolidine } \\
\text { pyrrolidine }\end{array}$ & 31268 & Sperm, Bleach \\
\hline $\begin{array}{l}\text { Dimethyl disulfide } \\
\text { (methyldisulfanyl)methane }\end{array}$ & 12232 & Gas, Sulfur \\
\hline $\begin{array}{l}\text { Hexenol } \\
\text { (Z)-hex-3-en-1-ol }\end{array}$ & 5281167 & Cut grass \\
\hline $\begin{array}{l}\text { Trimethylamine } \\
\text { N,N-dimethylmethanamine }\end{array}$ & 1146 & Fishy, Amine \\
\hline $\begin{array}{l}\text { Calone } \\
\text { 7-methyl-1,5-benzodioxepin-3-one }\end{array}$ & 120101 & Marine, Cucumber \\
\hline $\begin{array}{l}\text { Ethyl isobutyrate } \\
\text { ethyl 2-methylpropanoate }\end{array}$ & 7342 & Fruity (strawberry, overripe kiwi) \\
\hline $\begin{array}{l}\text { Butyric acid } \\
\text { butanoic acid }\end{array}$ & 264 & Cheese (parmesan) \\
\hline \begin{tabular}{l} 
talics indicate IUPAC (International Union \\
\hline
\end{tabular}
\end{tabular}

857 Italics indicate IUPAC (International Union of Pure and Applied Chemistry) names 


\begin{tabular}{|c|c|c|c|c|c|c|c|c|}
\hline & & \multirow{2}{*}{$\begin{array}{l}\text { D0 } \\
\text { Fresh tuna }\end{array}$} & \multicolumn{3}{|l|}{ D8 } & \multicolumn{3}{|l|}{ D13 } \\
\hline & & & AIR & VP & MAP & AIR & VP & MAP \\
\hline Spoilage score* & & $2.08 \pm 1.08^{\mathrm{a}}$ & $1.92 \pm 1.16^{\mathrm{a}}$ & $3.00 \pm 1.41^{\mathrm{a}}$ & $3.07 \pm 2.09^{\mathrm{a}}$ & $6.33 \pm 1.78^{b}$ & $6.75 \pm 2.53^{b}$ & $6.83 \pm 1.99^{b}$ \\
\hline \multicolumn{9}{|l|}{ Odor } \\
\hline$\overline{\text { Level }}^{\star *}$ & & $2.25 \pm 0.96^{\mathrm{acd}}$ & $1.75 \pm 0.96^{\mathrm{ac}}$ & $3.00 \pm 0.82^{\mathrm{ab}}$ & $1.40 \pm 0.55^{\mathrm{a}}$ & $6.25 \pm 2.22^{b c}$ & $7.50 \pm 1.29^{b}$ & $6.50 \pm 3.00^{\mathrm{bd}}$ \\
\hline \multirow[t]{4}{*}{ Characteristics $(\mathrm{I})^{\star * *}$} & marine & 2.00 & 2.00 & 1.25 & 1.80 & 1.00 & 0.75 & 1.00 \\
\hline & amine & 0.00 & 0.00 & 0.00 & 0.20 & 1.50 & 1.75 & 1.50 \\
\hline & sulfur & 0.00 & 0.00 & 0.00 & 0.00 & 0.00 & 1.50 & 0.50 \\
\hline & pungent & 0.00 & 0.00 & 0.00 & 0.00 & 0.25 & 1.25 & 0.75 \\
\hline \multicolumn{9}{|l|}{ Color } \\
\hline Level $^{* *}$ & & $1.75 \pm 0.96^{\mathrm{a}}$ & $2.75 \pm 1.50^{\mathrm{ab}}$ & $3.75 \pm 1.71^{a b c}$ & $5.00 \pm 2.00^{\mathrm{bc}}$ & $7.00 \pm 1.15^{\mathrm{cd}}$ & $8.50 \pm 1.29^{d}$ & $7.00 \pm 0.82^{c d}$ \\
\hline \multirow[t]{6}{*}{ Characteristics $(\mathrm{I})^{\star \star * *}$} & blood red & 2.25 & 1.25 & 1.50 & 1.20 & 0.00 & 0.25 & 0.25 \\
\hline & slightly pink & 1.25 & 1.00 & 1.50 & 2.20 & 0.75 & 0.25 & 1.25 \\
\hline & bleached & 0.00 & 0.00 & 0.00 & 0.00 & 1.25 & 0.00 & 1.00 \\
\hline & grayish & 0.00 & 0.00 & 0.00 & 0.00 & 1.00 & 0.50 & 1.50 \\
\hline & browned & 0.00 & 0.00 & 0.00 & 0.00 & 1.25 & 2.50 & 1.25 \\
\hline & greenish & 0.00 & 0.00 & 0.00 & 1.40 & 1.00 & 0.25 & 1.25 \\
\hline \multicolumn{9}{|l|}{ Texture } \\
\hline Level $^{* \star}$ & & $2.25 \pm 1.50^{\mathrm{ab}}$ & $1.25 \pm 0.50^{\mathrm{a}}$ & $2.25 \pm 1.50^{\mathrm{ab}}$ & $2.80 \pm 1.64^{\mathrm{abc}}$ & $5.75 \pm 2.06^{b c}$ & $4.25 \pm 2.63^{\mathrm{abc}}$ & $7.00 \pm 2.16^{\mathrm{c}}$ \\
\hline
\end{tabular}

AIR: Tuna stored under air at $0^{\circ} \mathrm{C}$; VP: Tuna stored u nder vacuum packaging at $4^{\circ} \mathrm{C}$ for 7 days followed by $8^{\circ} \mathrm{C}$; MAP: Tuna stored under modified atmosphere pa ckaging $(70 \%$ $\mathrm{CO}_{2}, 30 \% \mathrm{O}_{2}$ ) at $4^{\circ} \mathrm{C}$ for 7 days followed by $8^{\circ} \mathrm{C}$.

$a, b, c, d$ Tukey HSD test on ANOVA results $(p<0.05)$. Attribute scores with the same letter are noted significantly different $(p<0.05)$.

* Mean of the overall rating of odor, color and texture \pm SD.

** Panel mean score (scale from 0: non-spoiled to 10: very spoiled) \pm SD.

${ }^{* *} I=(1 \times$ percentage of panelists who selected slight $+2 \times$ percentage of panelists who selected moderate $+3 \times$ percentage of panelists who selected strong $) / 100$. 
866 Table 3: Estimated sample coverage (ESC) and OTU diversity and richness of the 867 16S rRNA gene libraries from the Illumina sequencing analyses of fresh tuna (D0) 868 and tuna packed (AIR, VP and MAP) at each date of sampling (D).

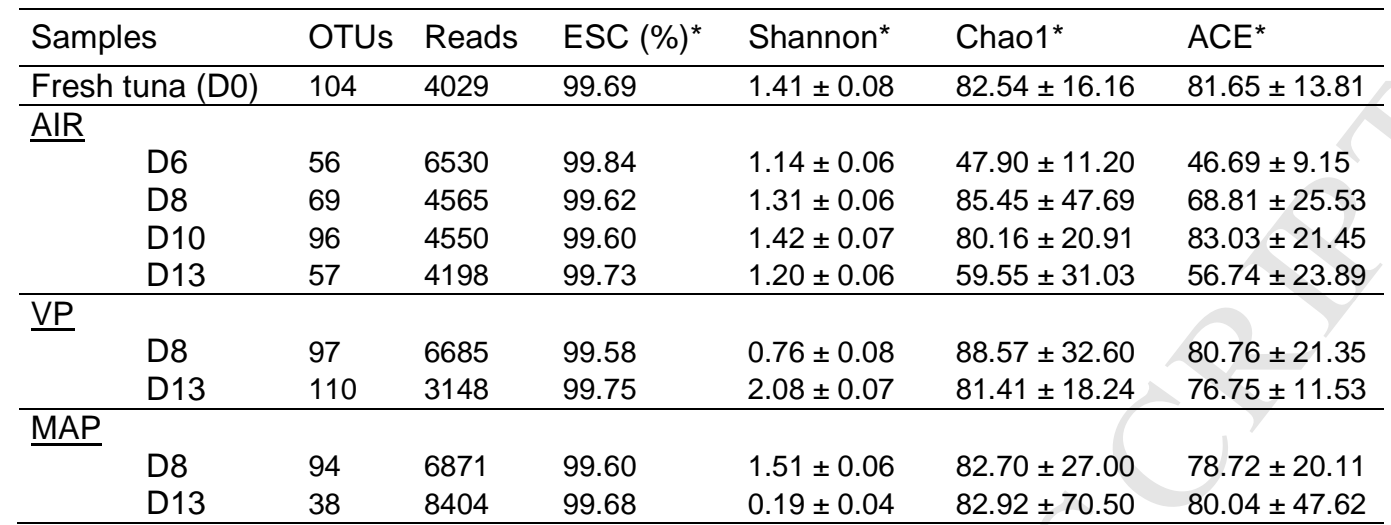

869 AIR: Tuna stored under air at $0^{\circ} \mathrm{C}$; VP: Tuna stored un der vacuum packaging at $4{ }^{\circ} \mathrm{C}$ for 7 days followed by $8^{\circ} \mathrm{C}$;

870 MAP: Tuna stored under modified atmosphere packaging $\left(70 \% \mathrm{CO}_{2}, 30 \% \mathrm{O}_{2}\right)$ at $4{ }^{\circ} \mathrm{C}$ for 7 days followed by $8{ }^{\circ} \mathrm{C}$;

871 OTUs: Operational taxonomic units; ESC: Estimated sample coverage.

872 * Calculated with MOTHUR at the $3 \%$ distance level (values \pm SD). 
873 Table 4: Sequence-read counts of bacterial genera/species identified by Illumina

874 Illumina sequencing for fresh tuna (D0) and for each storage trial (AIR, VP and MAP)

875 at each date of sampling (D). Unclassified represents genera/species not assigned

876 OTUs.

\begin{tabular}{|c|c|c|c|c|c|c|c|c|c|}
\hline \multirow{2}{*}{$\begin{array}{c}\text { OTUs } \\
\text { (genera/species level) }\end{array}$} & \multirow{2}{*}{$\begin{array}{l}\text { Fresh } \\
\text { tuna } \\
\text { D0 }\end{array}$} & \multicolumn{4}{|l|}{ AIR } & \multicolumn{2}{|l|}{ VP } & \multicolumn{2}{|l|}{ MAP } \\
\hline & & D6 & D8 & D10 & D13 & D8 & D13 & D8 & D13 \\
\hline Brochothrix thermosphacta & 211 & 5901 & 2849 & 2579 & 2796 & 6319 & 1132 & 2262 & 8310 \\
\hline Rhodanobacter terrae & 3069 & 11 & 32 & 155 & 3 & 2 & 1 & 4194 & 1 \\
\hline Pseudomonas sp. & 5 & 398 & 868 & 737 & 1217 & 27 & 104 & 6 & 13 \\
\hline Hafnia paralvei & 0 & 8 & 0 & 0 & 0 & 42 & 877 & 0 & 0 \\
\hline Pseudomonas deceptionensis & 0 & 34 & 310 & 492 & 0 & 11 & 0 & 0 & 0 \\
\hline Pseudomonas teatrolens & 0 & 27 & 329 & 365 & 0 & 5 & 0 & 0 & 0 \\
\hline Lactococcus sp. & 0 & 2 & 1 & 0 & 0 & 61 & 451 & 0 & 2 \\
\hline Brochothrix sp. & 31 & 71 & 35 & 56 & 68 & 61 & 86 & 34 & 49 \\
\hline Lactococcus piscium & 0 & 0 & 0 & 0 & 0 & 0 & 116 & 0 & 0 \\
\hline Carnobacterium sp. & 2 & 1 & 0 & 4 & 0 & 15 & 72 & 10 & 3 \\
\hline Carnobacterium maltaromaticum & 3 & 0 & 3 & 2 & 0 & 54 & 8 & 3 & 0 \\
\hline Methyloversatilis sp. & 37 & 0 & 0 & 0 & 2 & 0 & 0 & 9 & 0 \\
\hline Pseudomonas collierea & 39 & 0 & 0 & 0 & 3 & 0 & 0 & 0 & 0 \\
\hline Ralstonia sp. & 27 & 0 & 0 & 0 & 0 & 0 & 0 & 8 & 0 \\
\hline Hafnia sp. & 0 & 0 & 0 & 0 & 0 & 5 & 29 & 0 & 0 \\
\hline Lactobacillus crispatus & 0 & 15 & 1 & 1 & 0 & 9 & 2 & 1 & 0 \\
\hline Bacteroides vulgatus & 0 & 0 & 0 & 0 & 0 & 0 & 21 & 2 & 3 \\
\hline Streptococcus salivarius & 0 & 2 & 0 & 2 & 0 & 10 & 0 & 4 & 5 \\
\hline Burkholderia sp. & 20 & 0 & 0 & 0 & 0 & 0 & 0 & 0 & 0 \\
\hline Flavobacterium frigidarium & 0 & 0 & 0 & 12 & 0 & 0 & 0 & 8 & 0 \\
\hline Pseudomonas psychrophila & 0 & 6 & 11 & 2 & 0 & 0 & 0 & 0 & 0 \\
\hline Pseudomonas syncyanea & 0 & 4 & 12 & 1 & 0 & 0 & 0 & 1 & 0 \\
\hline Rhodanobacter sp. & 17 & 0 & 0 & 0 & 0 & 0 & 0 & 0 & 0 \\
\hline Lactobacillus salivarius & 0 & 0 & 0 & 1 & 0 & 12 & 0 & 0 & 1 \\
\hline Hydrogenophilus sp. & 13 & 0 & 0 & 0 & 0 & 0 & 0 & 0 & 0 \\
\hline Leuconostoc gelidum & 0 & 1 & 0 & 0 & 0 & 0 & 8 & 3 & 0 \\
\hline Propionibacterium acnes & 3 & 0 & 1 & 2 & 0 & 0 & 0 & 6 & 0 \\
\hline Psychrobacter glacincola & 11 & 0 & 0 & 0 & 0 & 0 & 0 & 0 & 0 \\
\hline Shewanella arctica & 0 & 0 & 0 & 11 & 0 & 0 & 0 & 0 & 0 \\
\hline Lactobacillus sp. & 1 & 0 & 0 & 0 & 9 & 0 & 0 & 0 & 0 \\
\hline Prevotella sp. & 0 & 3 & 2 & 0 & 0 & 4 & 0 & 0 & 0 \\
\hline Staphylococcus epidermis & 0 & 9 & 0 & 0 & 0 & 0 & 0 & 0 & 0 \\
\hline Pseudarcicella sp. & 0 & 1 & 0 & 1 & 0 & 0 & 6 & 0 & 0 \\
\hline Psychrobacter sp. & 8 & 0 & 0 & 0 & 0 & 0 & 0 & 0 & 0 \\
\hline Psychrobacter arcticus & 8 & 0 & 0 & 0 & 0 & 0 & 0 & 0 & 0 \\
\hline Photobacterium sp. & 6 & 0 & 0 & 0 & 0 & 0 & 0 & 0 & 0 \\
\hline Staphylococcus sp. & 6 & 0 & 0 & 0 & 0 & 0 & 0 & 0 & 0 \\
\hline Telluria sp. & 0 & 0 & 4 & 2 & 0 & 0 & 0 & 0 & 0 \\
\hline Bacillus sp. & 0 & 0 & 0 & 0 & 5 & 0 & 0 & 0 & 0 \\
\hline Granulicatella sp. & 4 & 0 & 0 & 0 & 0 & 0 & 0 & 0 & 0 \\
\hline Propionibacterium sp. & 0 & 0 & 0 & 0 & 0 & 0 & 1 & 3 & 0 \\
\hline Pelomas sp. & 3 & 0 & 0 & 0 & 0 & 0 & 0 & 0 & 0 \\
\hline Achromobacter arsenitoxydans & 2 & 0 & 0 & 0 & 0 & 0 & 0 & 0 & 0 \\
\hline Aeromonas rivuli & 2 & 0 & 0 & 0 & 0 & 0 & 0 & 0 & 0 \\
\hline Alistipes sp. & 0 & 0 & 0 & 0 & 2 & 0 & 0 & 0 & 0 \\
\hline Lactococcus lactis & 2 & 0 & 0 & 0 & 0 & 0 & 0 & 0 & 0 \\
\hline Shigella sp. & 2 & 0 & 0 & 0 & 0 & 0 & 0 & 0 & 0 \\
\hline Lactobacillus algidus & 0 & 0 & 0 & 0 & 0 & 1 & 0 & 0 & 0 \\
\hline Unclassified & 497 & 36 & 107 & 125 & 93 & 47 & 234 & 317 & 17 \\
\hline Total & 4029 & 6530 & 4565 & 4550 & 4198 & 6685 & 3148 & 6871 & 8404 \\
\hline
\end{tabular}




\section{Figure 1}

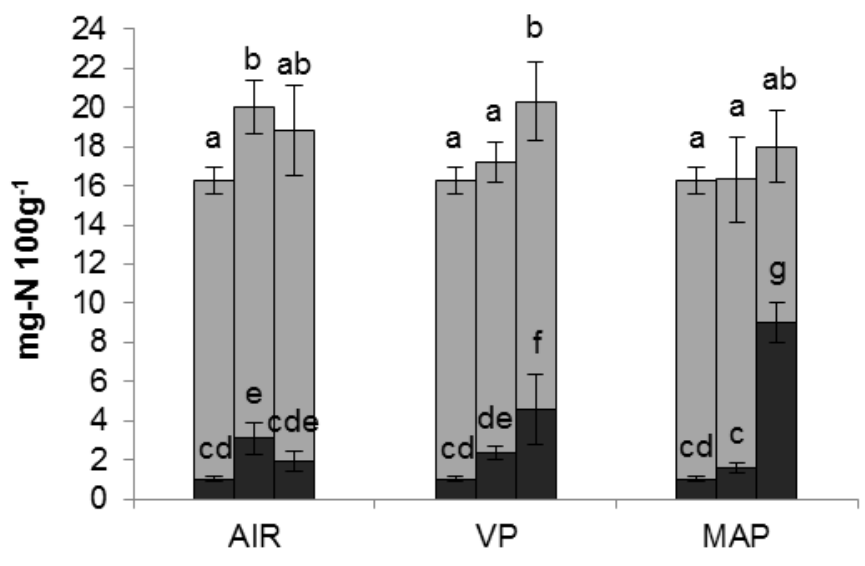

2 
$1 \quad$ Figure 2

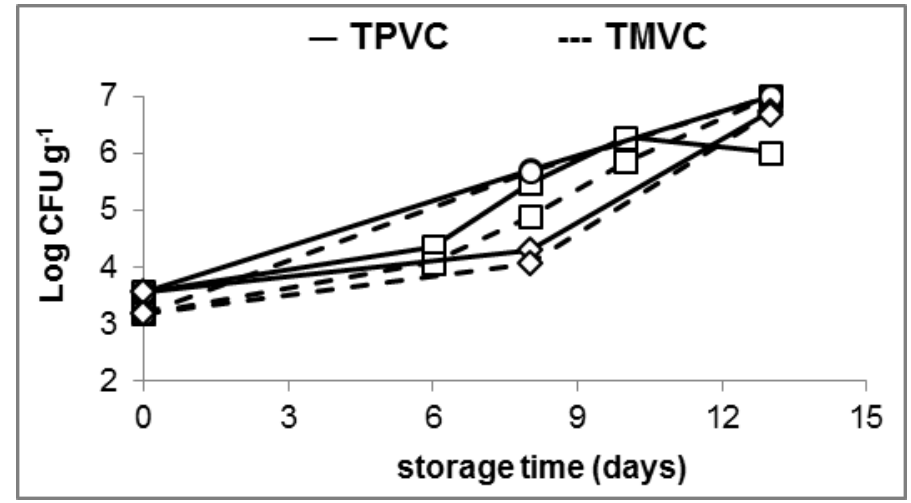

3
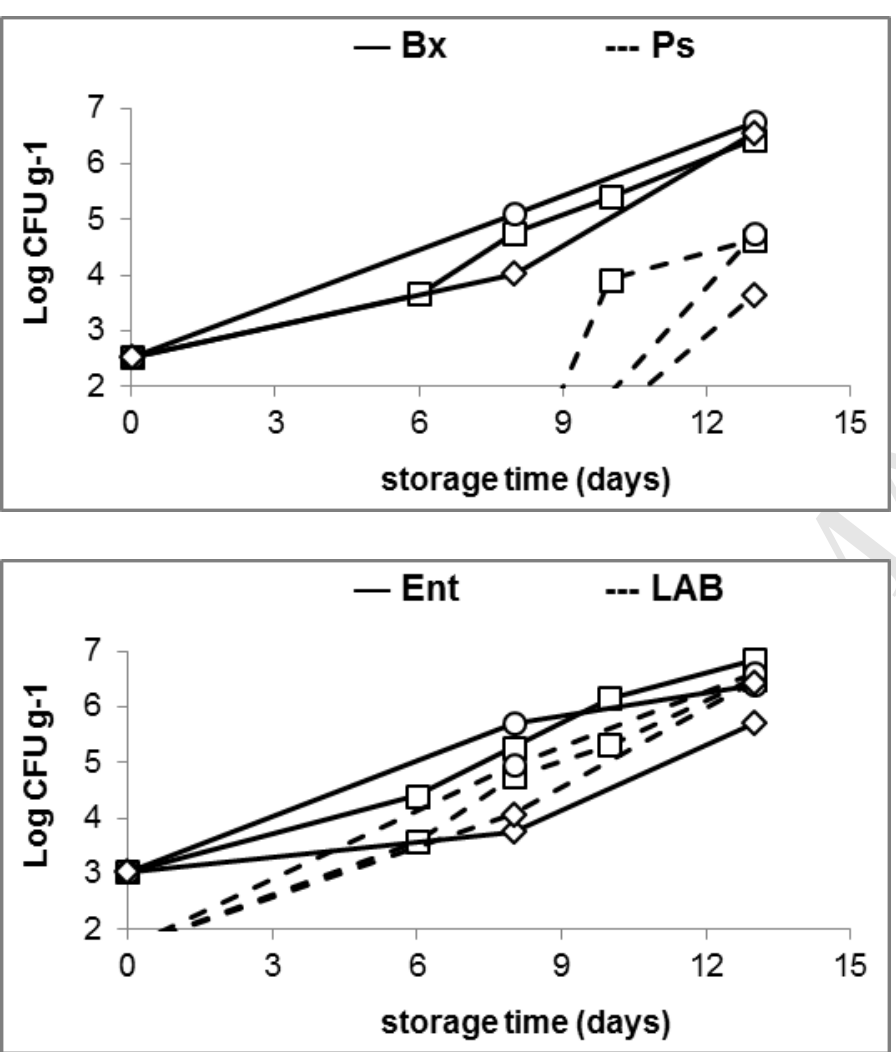
1 Figure 3

ITGE

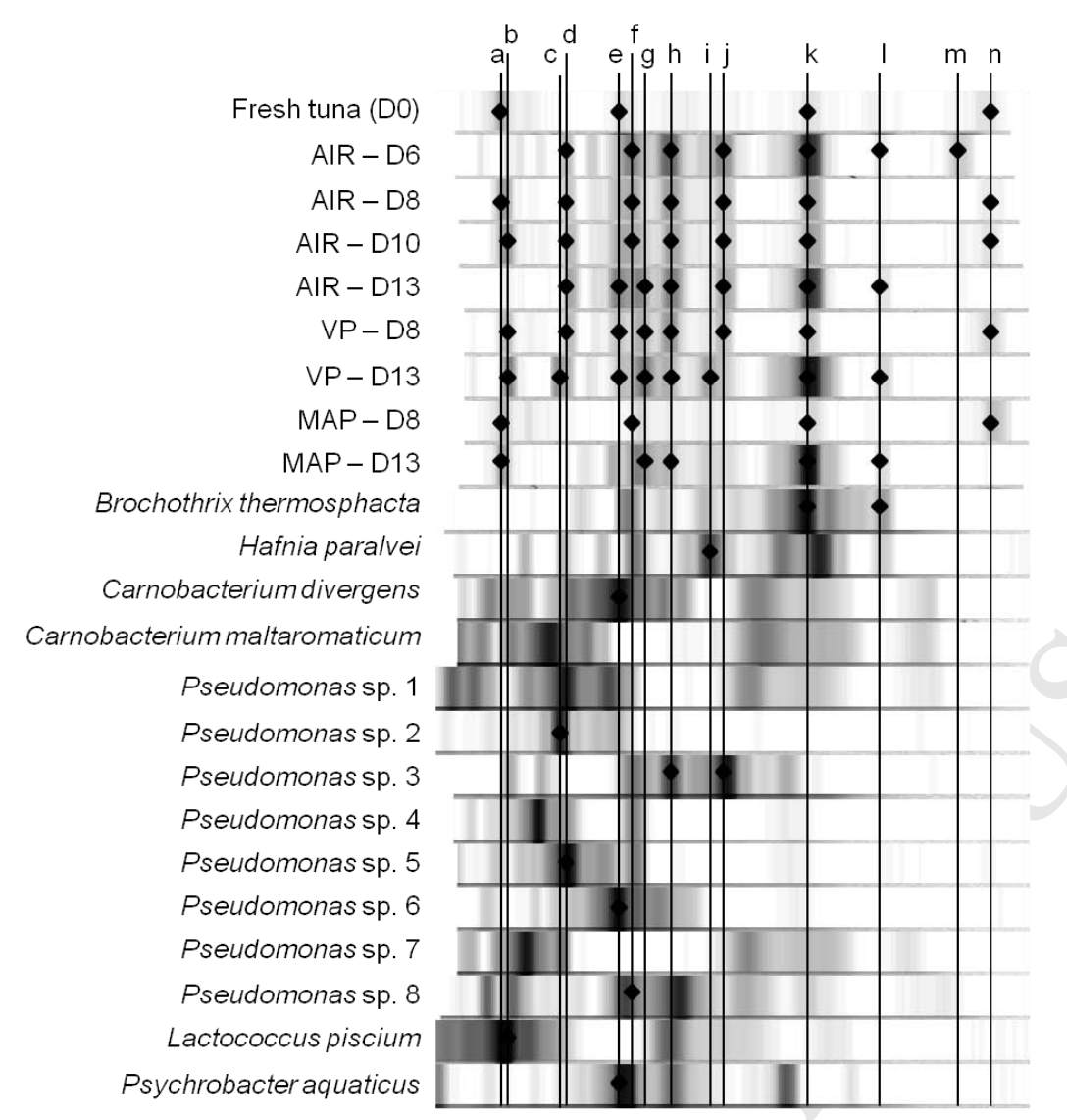


1 Figure 4

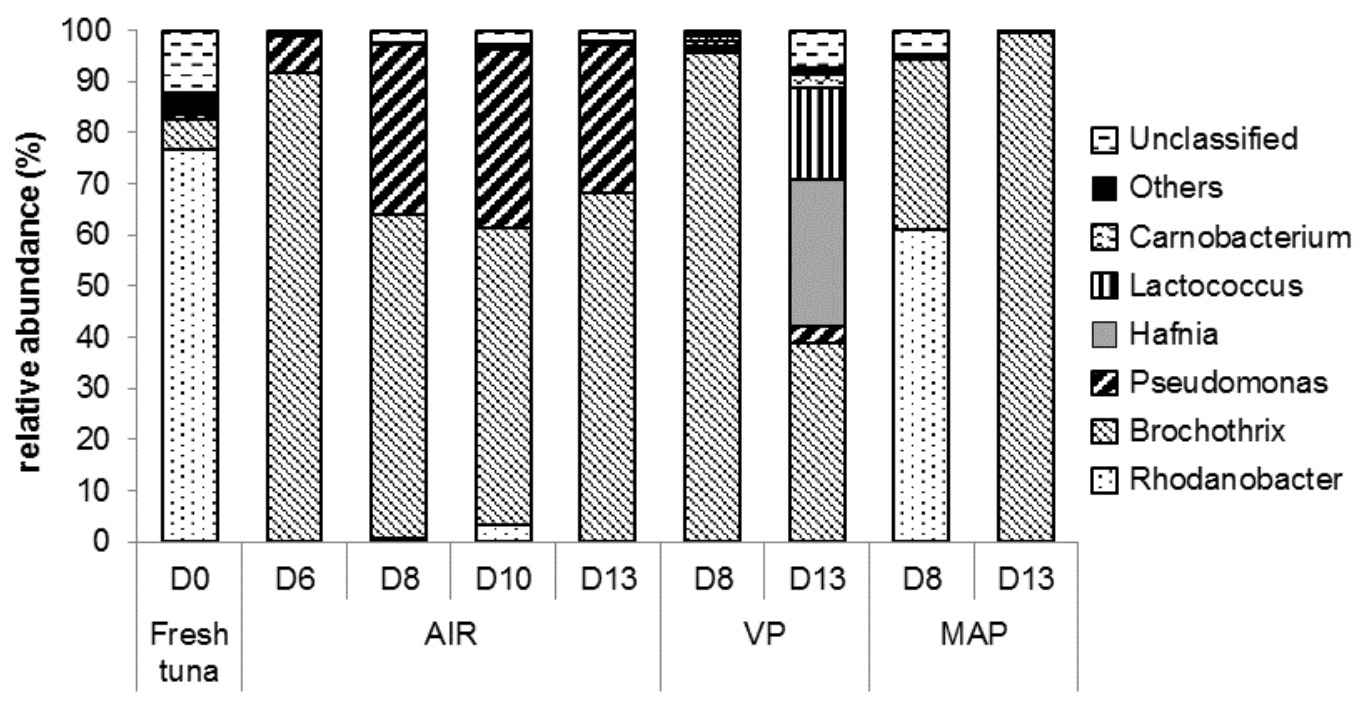




\section{$1 \quad$ Highlights}

2 -A polyphasic approach to characterize the microbial ecosystem of tuna is described

3 -Rhodanobacter terrae, never isolated from seafood, is dominant in fresh tuna

4 -Tuna placed under air, vacuum and modified atmosphere have the same shelf-life

5 -Brochothrix thermosphacta is the main bacterial species found in spoiled tuna

6 -A significant reduction in histamine is detected at the sensory rejection point 